\title{
Ana Cristina Cesar: um sopro de vida
}

Adilson Citelli*

Professor titular do Departamento de Comunicações e Artes da ECA/USP, onde ministra cursos de graduação e pós-graduação. Orienta dissertações e teses nas áreas de Comunicação e Linguagem, com ênfase nas subáreas Comunicação/Educação, Comunicação/Linguagem. É coeditor da revista Comunicação \& Educação, bem como pesquisador $1 C$ do CNPQ. ** E-mail: citelli@uol.com.br

Ana Cristina Cesar, ou Ana C., faria 60 anos no próximo 2 de julho. Nascida em 1952, suicidou-se em 29 de outubro de 1983. A revista Comunicação E Educação presta homenagem a esta poeta, tradutora, crítica literária, colaboradora de jornais e revistas e roteirista de televisão, e figura presente no debate sobre os rumos da arte, da produção cultural, da política, naquela difícil passagem dos anos 1970/1980 no Brasil. Ao curto tempo de vida, correspondeu intensa atividade intelectual marcada por uma produção de rara qualidade, que colocou Ana C. entre os nomes fundamentais na produção poética brasileira contemporânea. Vários de seus escritos póstumos vêm sendo publicados desde 1985.

Ana Cristina Cesar nasceu no Rio de Janeiro, mas se fez cidadã do mundo em constantes viagens. Cursou Letras na PUC/Rio e realizou mestrado em Comunicação pela UFRJ. Passou dois períodos na Inglaterra, em 1968 e em 1980,

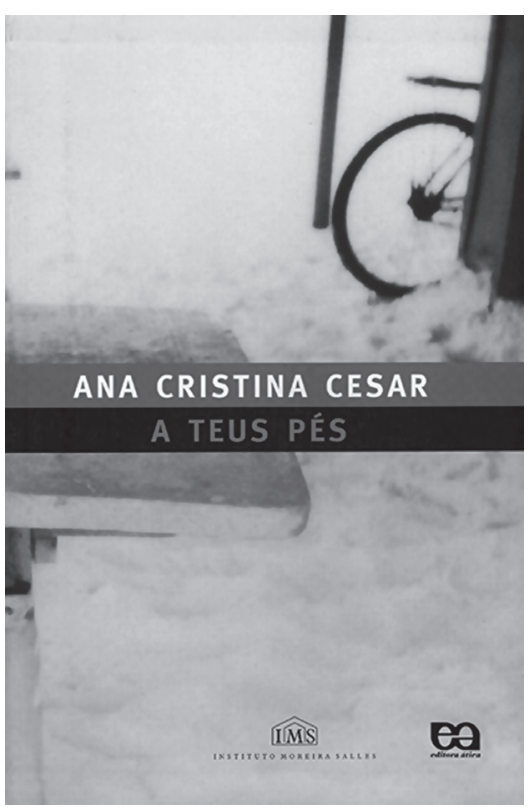

Capa de uma das edições de $A$ teus pés, de Ana Cristina César. quando cursou, na Universidade de Essex, Artes e Teoria e Prática da Tradução Literária.

A sua extensa obra ganhou destaque com o livro de poemas A teus pés, publicado em 1982 pela Editora Brasiliense, na paradigmática coleção Cantadas Literárias, responsável pelo lançamento de uma série de novos autores - muitos deles que fizeram parte da chamada "geração do mimeógrafo" ou "poesia marginal”. A Editora Ática vem reeditando A teus pés.

A poesia de Ana C. é marcada pelo tom confessional e intimista, conquanto inserida em estratégias de linguagem inovadoras, às quais se aliam o escrito curto, a composição próxima da prosa, a fragmentação, o texto colagem e o jogo irônico, como se lerá no poema "Flores do mais" - jogo com o título
* Com a colaboração de Cristine Vargas (revista Comunicação \& Educação - ECA/USP e FFLCH/ USP).

** É autor de inúmeros artigos e livros, dentre os quais se destacam: Linguagem e persuasão (Ática, 1994); Comunicação e Educação: a linguagem em movimento (Senac, 2000); Palavras, meios de comunicação e educação (Cortez, 2006). 
comunicação \& educação • Ano XVII • número 1 • jan/jun 2012

do poema de Charles Baudelaire, "As flores do mal" -, o comentário metalinguístico acerca do fazer literário. Em síntese esclarecedora, escreve Arminda Silva de Serpa (1999:55):

Os poemas de Ana Cristina Cesar, inserida no clima da geração 70, revelam, entre as muitas características que marcaram a produção poética daquela época, as seguintes: atração pelo insólito do cotidiano; ênfase na experiência existencial num momento especialmente difícil da história e da política brasileira; volta à primeira pessoa, à escrita da paixão e do medo como caminho eficaz no sentido de romper o silêncio e a perplexidade que tomaram de assalto a produção cultural no início da década; o sentido de asfixia, experimentado no cotidiano, mas trabalhado com humor; valorização do coloquialismo; culto do instante, eixo fundamental da nova poesia e do binômio arte e vida. O binômio arte e vida era a consolidação de uma visão de mundo que valorizava o aqui e o agora: a ideia do presente, eliminando a ideia de futuro.

Os poemas a seguir foram extraídos de A teus pés.

\section{FLORES DO MAIS}

devagar escreva

uma primeira letra

escreva

nas imediações construídas

pelos furacões;

devagar meça

a primeira pássara

bisonha que

riscar

o pano de boca

aberto

sobre os vendavais;

devagar imponha

o pulso

que melhor

souber sangrar

sobre a faca

das marés;

devagar imprima

o primeiro

olhar

sobre o galope molhado

dos animais; devagar

peça mais

e mais e

mais 


\section{Voando com o pássaro}

Tu queres sono: despe-te dos ruídos, e dos restos do dia, tira da tua boca

o punhal e o trânsito, sombras de teus gritos, e roupas, choros, cordas e também as faces que assomam sobre a tua sonora forma de dar, e os outros corpos que se deitam e se pisam, e as moscas que sobrevoam o cadáver do teu pai, e a dor [ (não ouças)

que se prepara para carpir tua vigília, e os [ cantos que esqueceram teus braços e tantos movimentos que perdem teus silêncios, o os ventos altos que não dormem, que te olham da janela e em tua porta penetram como loucos pois nada te abandona nem tu ao sono.

\section{SONETO}

Pergunto aqui se sou louca Quem quer saberá dizer Pergunto mais, se sou sã E ainda mais, se sou eu

Que uso o viés pra amar E finjo fingir que finjo Adorar o fingimento Fingindo que sou fingida

Pergunto aqui meus senhores quem é a loura donzela que se chama Ana Cristina

E que se diz ser alguém

É um fenômeno mor Ou é um lapso sutil?

\section{CONVERSA DE SENHORAS}

Não preciso nem casar

Tiro dele tudo o que preciso

Não saio mais daqui 
comunicação \& educação • Ano XVII • número 1 • jan/jun 2012

\author{
Duvido muito \\ Esse assunto de mulher já terminou \\ $\mathrm{O}$ gato comeu e regalou-se \\ Ele dança que nem um realejo \\ Escritor não existe mais \\ Mas também não precisa virar deus \\ Tem alguém na casa \\ Você acha que ele aguenta? \\ Sr. ternura está batendo \\ Eu não estava nem aí \\ Conchavando: eu faço a tréplica \\ Armadilha: louca pra saber \\ Ela é esquisita \\ Também você mente demais \\ Ele está me patrulhando \\ Para quem você vendeu seu tempo? \\ Não sei dizer: fiquei com o gauche \\ Não tem a menor lógica \\ Mas e o trampo? \\ Ele está bonzinho \\ Acho que é mentira \\ Não começa
}

\title{
INVERNO EUROPEU
}

Daqui é mais difícil: país estrangeiro, onde o creme de leite é desconjunturado e a subjetividade se parece com um roubo inicial. Recomendo cautela; "Não sou personagem do seu livro e nem que você queira não me recorta no horizonte teórico da década passada. Os militantes sensuais passam a bola: depressão legítima ou charme diante das mulheres inquietas que só elas? Manifesto: segura a bola; eu de conviva não digo nada e indiscretíssima descalço as luvas (no máximo), à direita de quem entra.

\section{REFERÊNCIAS BIBLIOGRÁFICAS}

CESAR, Ana Cristina. A teus pés. São Paulo: Brasiliense, 1982.

SILVA E SERPA, Arminda. Lições sobre asas e abismos: uma leitura da poesia de Ana Cristina Cesar. Fortaleza: Imprece, 2009. 